\title{
On the practical teaching system of the major of scenic development and management in vocational college \\ Xu Qiaomei
}

\author{
Research Department of Chongqing Business Vocational College, Chongqing, China \\ cqszyzcp@163.com
}

\begin{abstract}
Keywords: vocational college, the development and management of scenic area, practical teaching system.
\end{abstract}

\begin{abstract}
As the key link and feature of vocational education, the practical teaching is irreplaceable for the personal training and directly relates to the success of vocational education. With its strong practicality, the major of scenic development and management fosters managing and service talents in the forefront of tourism. This major emphasizes the integration between theory and practice in teaching while the practical teaching is of great importance in the whole teaching system. On the basis of the analysis of the existing problems, this article has explored the construction principle and mode of the practical teaching system of the major of scenic development and management in vocational college.

As the key link and feature of vocational education, the practical teaching is irreplaceable for the personal training and directly relates to the success of vocational education. By Tao Xingzhi, Chinese famous educator, the common problem of our education is the separation between theory and practice, and the solution lies in the combination of brain and hand. It is a must for the vocational college to emphasize the integration of theory and practice and establish a scientific and reasonable practical teaching system for fostering professional talents adaptable to the requirements of social market.
\end{abstract}

\section{The meaning of practical teaching in vocational college}

Taking the training of students' comprehensive capability as the main target, the practical teaching of vocational college constitutes the major part of vocational education. It is independent of but complementary to the theoretical education. Through observation, experiment, training and internship, the students' theoretical and professional knowledge has been consolidated and deepened, and their practical and innovative capabilities also developed. With the common features of teaching and its unique characteristics, the practical teaching always contains the following contents:

The target often includes:

The teaching target is more than the skill and technique of certain position the students should master, but includes their capability of knowledge application and personality shaping.

With its independent teaching system, the practical teaching contains teaching target, curriculum and evaluation. The connection and coordination of these procedures will help to fully play the efficiency of practical teaching.

The practical teaching focuses on the students' principal status, arouses their learning interest through vocational situation and encourages them to acquire skills. And the teachers should do more than the traditional teachers by guiding and organizing the students. Therefore, the practical teaching is a process that the students explore and experience the society.

The existing problems of the practical teaching of the major of scenic development and management

The underdeveloped teaching conditions

Without enough money, many vocational colleges have to reduce teaching costs and can not 
improve the practical teaching conditions. The scenic development and management is a newly-emerging major, its social recognition degree is low and student source is limited. Meanwhile, some colleges do not invest enough in this major, and there is no stable cooperative relations between the schools and scenic areas or tourism enterprises.

The unscientific teaching system

The major of scenic development and management is short of a reasonable practical teaching system. On the one hand, the practical teaching contents are arbitrary, not consistent. There is a strong correlation between the core courses of this major, such as the scenic management and service, scenic development and plan, science of tourism resources. However, the teachers have their own plans and programmer which are arbitrary and in coherent. On the other hand, the management of practical teaching in vocational colleges is far from standardized while that of the theoretical teaching is formal and strict. Besides, the poor execution and unscientific evaluation of practical teaching also increase the undesirable effect of practical teaching.

The weak teaching resources

For the major of scenic development and management of vocational college, most teachers have little practical experience which is necessary for teaching. Thus, it is tough for these teachers to fulfill their teaching tasks in spite of their rich professional knowledge. Meanwhile, for most vocational colleges, the major of scenic development and management is a newly-emerged major, and the limited teaching staff increases the difficulty of improving the practical teaching to a large extent.

\section{The construction of the practical teaching system of the major of scenic development and management in vocational college}

The construction principles

The principle of target

The construction of the practical teaching system should focus on the objective and standard of talent training. This major in our school aims at training well-rounded practical talents who adapt to the market requirements, satisfy the forefront needs of the scenic development and management, and have a good professional knowledge of scenic service, marketing, and planning. This is the fundamental basis and starting point of the major of scenic development and management in our school.

The principle of practice

The construction of practical teaching system of vocational college should emphasize the principle of practice and the training of students' practical capability. That is to say, more efforts should be made in the course setting, classroom management and training bases. On the one hand, the vocational college can invite relevant experts to explore the course setting of the practical teaching. Meanwhile, the construction of training bases should be more efficiently. On the other hand, the teachers of practical teaching should encourage students to do the job and master skills by themselves during the teaching process. Obviously, it is necessary for teachers to make enough demonstrations. For example, they can take a scenic spot and make detailed illustration to students.

The principle of system

According to the principle of system, we should follow the law of cognition and the law of teaching, adopt theories of systems science and take into account the major features of scientism development and management to construct the practical teaching system, which focuses on the training of students' professional capability. During the process of the capability training, the mutual cooperation and reasonable labor division should be paid to attention to complement each others' advantages.

The principle of prediction

With the development of society and economy, the need of scenic spots for talents is undergoing profound changes, and the vocational college should advance with the times to renew the contents of practical teaching through new ideas and new techniques. It is only in this way that 
the graduates will be able to satisfy the requirements of the society and economy. Meanwhile, the vocational college should strengthen its cooperation with scenic spots to know the general trends of the tourist enterprises and the tourist industry. Besides, the college can invite the managing and front-line staff to start practical teaching for the students.

The construction mode

To establish the objective system

The objective system refers to the teaching content and standard through practice. It takes vocational capability training as the clue, and covers the evolution and composition of the capability system, including the practical operation skills, and comprehensive professional ability. The final target of practical teaching in vocational college is to train compound talents with high quality.

To set up the content system

The contents of practical teaching can be divided into teaching content and teaching mode. Generally speaking, the practical teaching of the major of scenic development and management mainly contains four parts, namely, the professional cognitive practice, the practice teaching, the comprehensive practical teaching and the substituted post exercitation. For teaching mode, the foreign Dual System of talent training mode, the Chinese Three-stage practical teaching system, the “ $2+1$ ” Work-integrated Learning teaching mode, and so on.

In this article, a circular mode of practical teaching is recommended, that is, to incorporate the professional practice and college training into the integrated curriculum to realize the embedded circulation of theoretical and practical courses. For example, courses such as Management and Service of Scenic Spots, Development and Planning of Scenic Spots, can grow into the integrated courses. Such a circular mode of practical teaching, requiring a relatively closer cooperation between vational college and enterprise, can solve the problem of college training being out of joint with enterprises' demand.

To found the management and evaluation system

The higher vocational education aims at the training of students' practical capability and attaches great importance to practicability and efficiency. For the major of scenic development and management, the theoretical and the practical teaching supplement and promote each other. It is only under a series of management documents that the practical teaching is implemented efficiently. These documents mainly include operational rules, basic environment, essential procedures and teachers' duty. As an important method of practical teaching and talent training, the evaluation system of practical teaching is designed for students' practical activities and the practical teaching system. Generally speaking, the evaluation of students' practical activities include the performance evaluation, the management and analysis of evaluation and the teaching quality evaluation, while the evaluation of practical teaching system covers the teaching target, content and condition.

To strengthen the teaching staff

As a new major in vocational college, the major of scenic development and management is characterized by limited and weak teaching resources and poor practice teaching. Thus, it is necessary to build a team of double-qualified teachers. The first is to improve the professional teachers' practical capability. The second is to constantly improve the structure of the teaching team of this major, and to strive for a team of double-qualified teachers. And the last is to gradually enlarge the proportion of part-time teachers with rich experiences and theories from relevant scenic areas or enterprises.

To invest more to improve the teaching conditions

More investigation will be a basis and guarantee for improving the quality of practical teaching. Because of the strong practicalness of this major, the vocational college should strengthen the construction of training bases, and implement the strategy of "combination of the production and study, cooperation between college and enterprise" to realize the triple-win of enterprise, college and students. For the vocational college, it is important to invest more in training bases. However, it' $s$ more important to strengthen the construction of the training and practice bases to guarantee 
the stability, standard and quality of the bases.

\section{References}

[1] Feng Xiaofei. On the practical teaching mode of the tourism major of vocational college. Master Dissertation of Liaoning Normal University, 2010(5).

[2] Yu Zhongwen. On the practical teaching of higher vocational and technical education.Tsinghua University Press,2004(7).

[3] Bai Dechun, Luo Dawei. Research and construction of the practical teaching system of the software major of vocational college.Education and Career, 2007(7).

[4] Zhou Guozhong. On the practical teaching system of the scenic area major of vocational college. Education and Career,2007(7).

[5] Yu Jiehua. Analysis and strategy of the practical teaching problems of vocational college. Education for Chinese After-school(Theory).2011(z2).

[6] Li Minping, Dai Chunfang. A probe into the practical teaching reform of the economy and management specialty. Education Exploitation, 2008(11). 